PEMBELAJAR: Jurnal Ilmu Pendidikan, Keguruan, dan Pembelajaran

Volume 2 Nomor 1 April 2018 hal 63-71

e-ISSN: 2549-9114 dan p-ISSN: 2549-9203

(Received: Januari-2018; Reviewed: Maret-2018; Published: April 2018)

\title{
Pengembangan Model Bimbingan Belajar Quantum Learning Untuk Meningkatkan Kemandirian Belajar
}

\author{
Rasnila Ariqah Abdullatif \\ Bimbingan dan Konseling, Universitas Negeri Makassar \\ Email: abdullatifrasnilaariqah@gmail.com
}

\begin{abstract}
This research is research of Development of Quantum Learning Guidance Model, to remind Student Independence Student in SMAN 3 Polewali aimed at: (1) To know the description of the students' needs on the development of Quantum Learning guidance model in SMA Negeri 3 Polewali. (2) To know the description of feasibility test and acceptance of learning guidance model of Quantum Learning in SMA Negeri 3 polewali (3) To know the description of Quantum Learning guidance model developed by the researcher. While the method used is the procedure research and development (research and development). Which is based on research stages by Borg and Gall. Data analysis uses qualitative and quantitative data analysis. The results showed that: (1) Development of guidance model Learning quantum learning to improve self-reliance Learning Students get high scoring scale from experts and the response Very good from teachers counseling guidance and students that is acceptable and feasible For use in SMA Negeri 3 Polewali (2) Product development in the form of model of learning guidance of quantum learning to improve student's learning independence has made it easier for teachers to implement the program because it has been arranged systematically.
\end{abstract}

Keywords: Quantum Learning and Learning Independence

\begin{abstract}
Abstrak : Penelitian ini adalah penelitian Pengembangan Model Bimbingan Belajar Quantum Learning, untuk meningatkan Kemandirian Belajar Siswa di SMAN 3 Polewali yang bertujuan : (1) Mengetahui gambaran kebutuhan siswa terhadap pengembangan model bimbingan belajar Quantum Learning di SMA Negeri 3 Polewali. (2) Mengetahui gambaran uji kelayakan dan keberterimaan model bimbingan belajar Quantum Learning di SMA Negeri 3 polewali (3) Mengetahui gambaran model bimbingan belajar Quantum Learning yang dikembangkan oleh peneliti. Sedangkan metode yang digunakan adalah prosedur penelitian dan pengembangan (research and development). yang berdasarkan tahapan-tahapan penelitian oleh Borg and Gall.Analisis data menggunakan analisis data kualitatif dan kuantitatif. Hasil penelitian menunjukkan bahwa : (1) Pengembangan model bimbingan Belajar quantum learning untuk meningkatkan kemandirian Belajar Siswa mendapat skala penilaian tinggi dari para ahli dan respon yang sangat baik dari guru bimbingan konseling serta siswa yaitu dapat diterima dan layak untuk digunakan di SMA Negeri 3 Polewali (2) Pengembangan produk berupa model bimbingan belajar quantum learning telah memudahkan guru pembimbing untuk melaksanakan program dan telah efektif untuk meningkatkan kemandirian belajar siswa di SMA Negeri 3 Polewali.
\end{abstract}

Kata Kunci : Quantum Learning dan Kemandirian Belajar

(O2018 -Pembelajar Universitas Negeri Makassar. Ini adalah artikel dengan akses terbuka dibawah licenci CC BY-NC-4.0 (https://creativecommons.org/licenses/by-nc/4.0/ ). 


\section{PENDAHULUAN}

Salah satu permasalahan yang seringkali dialami oleh siswa khususnya di tingkat SMA adalah tingkat kemandirian belajar siswa yang masih tergolong rendah khususnya pada tingkat sekolah menengah kejuruan dan sederajat. Rendahnya kemandirian belajar siswa berdampak pada banyaknya siswa yang mengalami kegagalan dalam memenuhi standar ketercapaian kelulusan yang telah ditetapkan oleh sekolah maupun pemerintah, dan pada akhirnya menurunkan kualitas pendidikan. Melihat fenomena rendahnya kemandirian belajar serta mengingat pentingnya kemandirian belajar dalam mencapai suatu keberhasilan, maka diperlukan adanya suatu upaya untuk menanggulangi permasalahan rendahnya kemandirian belajar siswa. Burtiham (1999) mengemukakan bahwa kemandirian belajar adalah salah satu bentuk perilaku yang dapat dikembangkan konselor sebagai fasilitator bagi siswa untuk mengembangkan diri, dituntut untuk menjalankan fungsinya. Ahman (1990) mengemukakan bahwa tingkat penerapan prinsip bimbingan memberikan konstribusi yang signifikan terhadap kemandirian belajar siswa yaitu sebesar $8,81 \%$. Hal ini berarti bahwa tingkat kemandirian belajar siswa disokong oleh tingkat penerapan prinsip bimbingan. Selain itu, penelitian Pujiastuti (2007) mengemukakan bahwa siswa yang memiliki kemandirian belajar tinggi, secara signifikan memiliki keterampilan menulis lebih baik dari pada siswa yang memiliki kemandirian belajar rendah. Hal ini terlihat dari perolehan $\mathrm{F}_{\text {hitung }}$ sebesar 44,71> $\mathrm{F}_{\text {tabel }}$ sebesar 3,94 pada taraf $\alpha=0,05$. Temuan ini mengisyaratkan bahwa peranan konselor tidak bisa diabaikan dalam meningkatkan kemandirian belajar siswa. Upaya pemberian bimbingan belajar turut memperbaiki kemandirian belajar siswa.

Bimbingan dan konseling merupakan bagian integral pendidikan yang berupaya mengembangkan potensi siswa, memberikan bantuan kepada semua siswa dalam seluruh aspek perkembangan siswa baik aspek belajar, sosial, pribadi maupun karir. Layanan bimbingan yang membantu siswa dalam mengatasi permasalahan belajar khususnya kemandirian belajar adalah bimbingan belajar.

Fenomena yang serupa di jumpai di SMA Negeri 3 Polewali. Berdasarkan hasil pengamatan yang dilakukan penulis dan data yang di peroleh melalui wawancara dengan kordinator BK dan guru mata pelajaran pada tanggal 20 Oktober 2016 di SMA Negeri 3 Polewali terdapat adanya permasalahan belajar yang muncul yaitu rendahnya kemandirian belajar siswa. Permasalahan belajar yang terjadi terlihat dari perilaku siswa yang menampakkan ketergantungan belajar pada kehadiran guru dikelas, kurang percaya diri, mencontek tugas dan ulangan, rendah dalam berusaha menambah pengetahuan dari berbagai sumber, belajar dengan sistem kebut semalam, rendahnya minat baca, rendahnya menggunakan sumber perustakaan, gemar berkeliran pada jam belajar, siswa sering mengabaikan pelajaran. Rendahnya kemandirian belajar siswa berdampak pada kegiatan belajar siswa disekolah. Siswa SMA Negeri 3 Polewali mengalami ketergantungan belajar pada kehadiran guru dikelas, kurang percaya diri, belajar dengan sistem kebut semalam, rendahnya minat baca, gemar berkeliaran pada jam belajar serta rendahnya usaha menambah pengetahuan dari berbagai sumber sehingga nilai mata pelajaran hampir turun drastis dari setiap semester

$$
\text { Kemandirian belajar merupakan }
$$
kekuatan motivasional bagi siswa dalam mencapai keberhasilan belajar. Kemandirian belajar merupakan salah satu aspek perkembangan yang menjadi masalah psikologis individu yang akan menghambat perkembangan selanjutnya, jika individu tidak mampu mengembangkannya secara optimal. Konselor sekolah sebagai seseorang yang memiliki fungsi untuk membantu menyelesaikan berbagai permasalahan psikologis siswa dituntut untuk mampu mengembangkan kemandirian belajar pada siswa SMA Negeri 3 Polewali sehingga siswa dapat mengoptimalkan potensi yang dimiliki serta mampu melihat peluang dan mampu menjadikan kehidupannya lebih bermakna.

Kemandirian belajar memegang peranan penting bagi siswa agar dapat melakukan sendiri tanpa bergantung kepada orang lain dalam melakukan aktifitas belajarnya. Siswa yang memiliki kemandirian belajar yang kuat dalam dirinya akan memiliki semangat untuk melakukan kegiatan belajar di kelas. Kemandirian belajar merupakan salah satu bentuk permasalahan belajar yang dianggap klasik sebagai gejala yang muncul di sekolah, 
namun merupakan salah satu faktor yang sangat penting ditangani secara bersama oleh pihak sekolah.

Bimbingan dan konseling di sekolah memegang peranan dalam menangani permasalahan belajar dan memiliki prinsip layanan bimbingan untuk semua siswa yang mempunyai permasalahan ataupun tidak di sekolah. Salah satu tugas yang menjadi tanggung jawab utama guru bimbingan dan konseling di sekolah adalah untuk memberikan arahan dan membimbing proses kegiatan belajar siswa. kemandirian belajar siswa merupakan salah satu langkah awal yang harus diberikan dalam pelayanan bimbingan dan konseling khususnya bimbingan belajar.

Bimbingan dan konseling hadir sebagai upaya pemberian bantuan kepada siswa agar mengembangkan diri secara optimal, memahami potensi diri dan lingkungan sehingga siswa dapat memiliki kompetensi yang di harapkan dan berguna untuk kesuksesan di masa depan. Pentingnya bimbingan belajar di buat agar siswa memiliki kesadaran dan kebiasaan belajar yang positif seperti kebiasaan membaca buku, memiliki motif belajar yang tinggi sepanjang hayat, memiliki kemandirian dalam belajar, serta di harapkan memiliki keterampilan atau teknik belajar yang efektif.

Terdapat beragam bimbingan belajar untuk meningkatkan kemandirian belajar siswa. Dapat dilakukan dengan menggunakan pendekatan teori-teori belajar. Siswa yang memiliki kemandirian belajar rendah salah satunya karena tidak mempunyai keterampilan belajar. Salah satu teori belajar yang menjelaskan mengenai keterampilan belajar adalah teori belajar Robert Gange dengan menggunakan metode belajar yang mampu mengembangkan keterampilan belajar siswa yaitu dengan metode SQ3R atau singkatan dari survey (menyelidiki), question (bertanya), read (membaca), recite (mengucapkan kembali), review (mengulang). Dalam menghafal cara ini dilakukan agar siswa mudah menghafal tapi bukan sekedar menghafal tapi juga memahami. Metode PQRST singkatan dari preview (menyelidiki), question (bertanya), read (membaca), state (menyatakan), test (menguji). Metode ini memudahkan pembaca untuk memahami isi dari bacaan dan juga memudahkan dalam mengingat kembali mengenai isi dari bacaan tersebut atau dengan metode Quantum Learning.
Hasil penelitian Jeannette Vos Groenendal (Deporter dan Hernacki, 2006:19) menyatakan bahwa bimbingan belajar quantum learning dipandang efektif karena quantum learning berhasil meningkatkan motivasi belajar siswa sebesar $68 \%$ yang dipengaruhi dengan memperbesar kepercayaan diri sebesar $81 \%$, dan nilai belajar sebesar $73 \%$. Penggunaan bimbingan belajar quantum learning diprediksi dapat digunakan untuk meningkatkan kemandirian belajar siswa karena faktor-faktor yang mempengaruhi kemandirian belajar adalah adanya kepercayaan diri, dan keterampilan belajar. Wlodkowski (2003) menyatakan bahwa model pembelajaran Quantum Learning signifikan meningkatkan keterampilan belajar sebesar 26 persen di banding dengan pembelajaran konvensional hanya 18 persen. Selain itu, (Rose, 2002) mengemukakan bahwa model pembelajaran Quantum Learning merupakan teknik pembelajaran alami, sesuai dengan gaya belajar siswa sehingga belajar terasa lebih mudah dan lebih cepat. Sehubungan hasil temuan di atas, dapat disimpulkan bahwa rendahnya kemandirian belajar siswa di sebabkan karena minimnya keterampilan belajar yang dimiliki oleh siswa yang bersangkutan. Maka model bimbingan belajar Quantum Learning sangat cocok digunakan untuk meningkatkan keterampilan belajar yang berpengaruh pada peningkatan kemandirian belajar siswa. Kemandirian belajar merupakan proses dimana individu mengambil inisiatif dalam merencanakan, melaksanakan dan mengevaluasi sistem pembelajarannya (Merriam \& Cafarella, 1999). Sedangkan menurut Grieve (2003) kemandirian belajar adalah atribut personal, kesiapan psikologis seseorang dalam mengontrol atau bertanggung jawab dalam prose belajarnya. Menurut Gibbons (2002), belajar mandiri merupakan peningkatan dalam pengetahuan, kemampuan, atau perkembangan individu dimana individu memilih dan menentukan sendiri tujuan dalam pembelajaran, berusaha menggunakan metode-metode yang mendukung kegiatannya. Sementara itu, Cyril Kesten (1992), mendefinisikan belajar mandiri sebagai sebagai suatu bentuk belajar dimana pebelajar dapat membuat keputusan-keputusan penting yang sesuai dengan kebutuhan belajarnya sendiri. Menurut Johnson (2002) kemandirian belajar memberi kebebasan kepada siswa untuk menemukan bagaimana kehidupan akademik sesuai dengan kehidupan sehari-hari. 
Pelajar mengambil keputusan sendiri dan menerima tanggung jawab untuk itu. Pelajar juga mengatur, menyesuaikan tindakan mereka untuk mencapai tujuan yang diiginkan.

Proses belajar mandiri ini memberikan siswa kesempatan yang luar biasa untuk mempertajam kesadaran mereka akan lingkungan mereka. Pembelajaran mandiri memungkinkan siswa untuk membuat pilihanpilihan positif tentang bagaimana pelajar akan mengatasi kegelisahan dan kekecauan alam kehidupan sehari-hari. Pola ini memungkinkan siswa bertindak berdasarkan inisiatis mereka sendiri untuk membentuk lingkungan.

Berdasarkan beberapa pendapat di atas, dapat disimpulkan bahwa kemandirian belajar adalah suatu proses belajar dimana setiap individu dapat mengambil inisiatif, dangan atau tanpa bantuan orang lain, dalam hal menentukan kegiatan belajarnya seperti merumuskan tujuan belajar, sumber belajar, mendiagnosa kebutuhan belajar, dan mengontrol sendiri proses pembelajarannya.

\section{METODE}

Model Pengembangan penelitian ini dilakukan dengan menggunakan pendekatan "Penelitian Pengembangan" (Research and Development). Menurut Borg \& Gall (2003: 782 ), penelitian dan pengembangan adalah " $A$ process used develop and validate educational product". Menurut Sugiyono (2010) bahwa Metode penelitian dan pengembangan atau di kenal dengan research and development adalah metode penelitian yang digunakan untuk menghasilkan produk tertentu dan menguji keefektifan produk tertentu.

Penelitan ini dilakukan pada siswa SMA Negeri 3 Polewali, setelah terlebih dahulu melakukan survey awal untuk memperoleh data informasi awal. Alasan dipilihnya siswa di SMA Negeri 3 Polewali karena dari hasil survey awal dan wawancara dengan guru pembimbing tanggal 20 Januari 2015 di SMA Negeri 3 Polewali diketahui bahwa program bimbingan belajar hanya mengikuti program secara nasional, tanpa mempertimbangkan perkembangan kebutuhan belajar siswa pada umumnya serta tidak adanya alokasi waktu khusus. Selain itu, peneliti juga menemukan adanya permasalahan belajar yang muncul yaitu rendahnya kemandirian belajar siswa hal ini terlihat dari perilaku siswa yang menampakkan ketergantungan belajar pada kehadiran guru dikelas, kurang percaya diri, mencontek tugas dan ulangan, rendah dalam berusaha menambah pengetahuan dari berbagai sumber, belajar dengan sistem kebut semalam, rendahnya minat baca, rendahnya menggunakan sumber perustakaan, gemar berkeliran pada jam belajar, siswa sering mengabaikan pelajaran.

Uji coba produk

Pada pengembangan model bimbingan belajar quantum learning untuk meningkatkan kemandirian belajar siswa dilakukan uji coba. Uji coba dilakukan pada uji kelompok kecil. Pada uji coba kelompok kecil melibatkan 6 siswa dari SMA Negeri 3 Polewali. Uji dimaksudkan untuk memperoleh data yang hasilnya akan dijadikan sebagai dasar merevisi produk, sehingga produk yang dihasilkan benarbenar layak untuk digunakan.

1. Subyek uji coba

Subyek uji kelompok kecil merupakan sekelompok kecil siswa kelas X yaitu 6 siswa yang mengalami kemandirian belajar rendah. Peneliti akan menggunakan teknik pemilihan sampel dengan cara purposive sampling atau sampel bertujuan. Menurut Arikunto (2002), purposive sampling dilakukan dengan cara mengambil subyek bukan didasarkan atas strata, random, atau daerah, tetapi didasarkan atas adanya tujuan tertentu. Hal itu sesuai pendapat Nasution (2000) bahwa penentuan subyek penelitian dengan teknik purposive sampling dilakukan dengan cara mengambil orang-orang yang terpilih betul oleh peneliti menurut ciri-ciri spesifik yang dimiliki oleh subyek tersebut. Dasar inilah peneliti memilih sampel sebanyak 6 orang sebagai uji coba kelompok kecil.

2. Jenis data

Data yang diperoleh dalam pengembangan model bimbingan belajar quantum learning untuk meningkatkan kemandirian belajar siswa berupa data kualitatif dan kuantitatif. Data kualitatif diperoleh dari hasil tanggapan, kritik atau saran dari para ahli dan hasil uji kelompok kecil terhadap rencana pengembangan program berupa model bimbingan belajar untuk meningkatkan kemandirian belajar siswa.

Data kuantitatif diperoleh dari uji kelompok kecil yang berupa penilaian secara umum mengenai model bimbingan belajar quantum learning. Data yang didapatkan kemudian diolah guna menunjukkan taraf 
kelayakan dan pada akhirnya, seluruh data baik data kuantitatif maupun kualitatif yang diperoleh akan digunakan sebagai dasar merevisi produk model bimbingan belajar quantum learning tersebut.

Instrumen pengumpulan data. Penelitian ini menggunakan 2 macam instrument pengambilan data, meliputi wawancara (Interview) dan Skala penilaian angket. Pengumpulan data dengan cara wawancara dilakukan untuk mengumpulkan data berupa tanggapan atau penilaian dari para ahli pada pengembangan model bimbingan belajar quantum learning untuk meningkatkan kemandirian belajar siswa. Proses wawancara melalui wawancara bebas terpimpin, dengan membuat garir-garis besar informasi yang ingin diperoleh. Sedangkan Alat pengumpulan data berupa angket digunakan untuk mengumpulkan data berupa tanggapan atau penilaian siswa SMA Negeri 3 Polewali. Bentuk angket yang digunakan oleh peneliti adalah gabungan bentuk angket tertutup dengan pilihan jawaban"ya' dan 'tidak" dan bentuk angket terbuka dimana responden dapat memberikan komentar pada setiap butir pertanyaan. Data yang diperoleh dari angket tersebut adalah data kuantitatif dan kualitatif berupa hasil atau skor lembar evaluasi yang diperoleh dari uji kelompok kecil.

Adapun Validitas instrumen dalam penelitian pengembangan ini khususnya berupa angket dilakukan dengan cara validitas logis. Menurut Ari Kunto (2002 : 167) Sebuah instrumen dikatakan memiliki validitas logis apabila instrumen tersebut secara analisis akal sudah sesuai dengan isi dan aspek yang diungkap, dan untuk memperoleh instrumen yang memiliki validitas logis baik dari isi maupun aspeknya, peneliti melakukan perencanaan penyusunan instrumen dengan membuat kisi-kisi instrumen. Selanjutnya, peneliti meminta pendapat ahli dalam mencermati kesesuaian instrumen yang telah disusun dengan hal-hal yang ingin diungkap.

Teknik analisis data yang digunakan untuk mengolah data yang diperoleh dalam pengembangan model ini adalah dengan menggunakan analisis isi dan analisis deskriptif.

Analisis data kualitatif dilakukan dengan menggunakan analisis isi, yaitu dengan mengelompokkan informasi-informasi data kualitatif berupa tanggapan, masukan, serta kritik dan saran yang didapat dari para ahli, ini digunakan untuk merevisi model bimbingan belajar quantum learning untuk meningkatkan kemandirian belajar siswa pada revisi tahap 1 .

Analisis data kuantitatif dilakukan dengan analisis deskriptif kuantitatif yaitu untuk menganalisis data kuantitatif diperoleh dari lembar evaluasi yang diperoleh dari uji kelompok kecil.

\section{HASIL DAN PEMBAHASAN}

Hasil analisis kebutuhan tidak hanya didasarkan pada asumsi-asumsi dalam menganalisis kebutuhan saja tetapi didasarkan juga pada hasil studi pendahuluan yang dilakukan oleh peneliti dengan teknik survei melalui wawancara (interview) dengan guru pembimbing dan siswa di SMA Negeri 3 Polewali.

Dari hasil survei melalui wawancara kepada tiga orang guru pembimbing di sekolah tersebut, diperoleh informasi-informasi bahwa siswa-siswa dalam proses belajarnya, yaitu kemandirian belajarnya masih sangat kurang atau rendah hal ini ditandai dari masih banyaknya siswa yang memiliki ketergantungan belajar pada kehadiran guru dikelas, kurang percaya diri, mencontek tugas dan ulangan, rendah dalam berusaha menambah pengetahuan dari berbagai sumber, belajar dengan sistem kebut semalam, rendahnya minat baca, rendahnya menggunakan sumber perustakaan, gemar berkeliran pada jam belajar, siswa sering mengabaikan pelajaran. Sehingga menurut guru pembimbing sangat perlu untuk diadakan model pembelajaran yang baru dan menarik untuk siswa, dalam hal ini model bimbingan belajar quantum learning.

Sejalan dengan pengamatan secara langsung yang dilakukan oleh peneliti di sekolah tersebut, masih sangat kurang siswa yang memiliki kemandirian belajar tinggi. Demikian pula dengan hasil wawancara yang didapatkan dari pengakuan siswa sebanyak 6 orang bahwa tingkat kemandirian belajarnya masih rendah hal ini menujukkan adanya siswa yang memiliki ketergantungan belajar pada kehadiran guru dikelas, kurang percaya diri, mencontek tugas dan ulangan, rendah dalam berusaha menambah pengetahuan dari berbagai sumber, belajar dengan sistem kebut semalam, rendahnya minat baca, rendahnya menggunakan sumber perpustakaan, gemar berkeliran pada jam belajar. Maka di tarik kesimpulan dari analisis 
kebutuhan yang dilakukan bahwa model bimbingan belajar quantum learning untuk meningkatkan kemandirian belajar siswa belum ada tersedia di sekolah, dan diharapkan untuk segera dilaksanakan guna membantu guru pembimbing dalam mengarahkan siswa dalam belajar. Peneliti melakukan penelitian pengembangan model bimbingan belajar quantum learning untuk membantu siswa meningkatkan kemandirian belajarnya di sekolah yaitu di SMA Negeri 3 Polewali.

Melalui kegiatan bimbingan belajar quantum learning peneliti melibatkan 6 siswa untuk kelompok terbatas (uji kelompok kecil). Hasil wawancara dengan 6 orang siswa kelas X SMA Negeri 3 Polewali, diperoleh data yang dapat disimpulkan bahwa sebagian besar dari siswa membutuhkan bimbingan belajar dengan model pembelajaran quantum learning guna membantu siswa dalam meningkatkan kemandirian belajarnya di sekolah sehingga siswa mampu memperoleh prestasi dan hasil belajar yang baik.

Hasil wawancara berdasarkan dari pedoman wawancara pada 6 orang siswa kelas $X$ SMA Negeri 3 Polewali.diuraikan sebagai berikut;

Berdasarkan 6 siswa kelas $\mathrm{X}$ yang diwawancara, siswa menuturkan mengetahui model pembelajaran quantum learning, namun hanya 1 siswa yang memiliki pemahaman lebih tentang quantum learning, selebihnya mengetahui hanya dari segi pengertian dalam bahasa Indonesia dan tidak tahu melaksanakannya.

Selanjutnya dari hasil penuturan 5 siswa yang masih belum mengerti mengenai bimbingan belajar quantum learning, siswa menuturkan bahwa istilah itu sebenarnya pernah didengar pada saat masih duduk di bangku sekolah menengah pertama pada saat guru bimbingan dan konseling menyampaikan layanan informasi dikelasnya, namun tidak begitu memperhatikan dan mengerti materi dan pelaksanaan yang diberikan oleh guru pembimbing. Kemudian dari penuturan oleh siswa yang sudah memiliki pemahaman lebih tentang model pembelajaran quantum learning yaitu 1 orang siswa, menurut penuturannya telah memperoleh pemahaman tentang model bimbingan belajar quantum learning yang telah didapatkan dari guru pembimbing yang memberikan layanan informasi.
Meskipun demikian, menurut keseluruhan objek wawancara mengharapkan adanya praktek secara langsung bimbingan belajar dengan model bimbingan belajar quantum learning dalam membantu mereka lebih mandiri dalam belajar di sekolah terlebih dalam proses belajar.

Berdasarkan wawancara dengan guru pembimbing didapatkan informasi pula bahwa model bimbingan belajar quantum learning sangat minim dalam proses pelaksanaanya. Pelaksanaan model bimbingan belajar quantum learning saat ini, sangat jarang untuk dilakukan karena belum adanya sistematika pelaksanaan yang efektif dan mudah untuk dilaksanakan oleh guru bimbingan dan konseling di sekolah. Para pendidik hanya mampu memberikan proses belajar yang bersifat monoton tanpa melihat dan membantu siswa untuk lebih mandiri dan kreatif dalam menciptakan proses belajarnya. Dikembangkannya model pembelajaran atau bimbingan belajar quantum learning sebagai panduan dalam meningkatkan kemandirian belajar siswa maka diharapkan mampu membantu siswa dalam mengelola gaya belajarnya lebih efektif khususnya siswa akan lebih mandiri mengikuti proses belajar.

Komponen pengembangan Model

1. Pengembangan model awal

Pengembangan model merupakan langkah dalam menyusun materi, sasaran model bimbingan belajar quantum learning serta waktu pelaksanaan kegaiatan. Awal penyusunan model bimbingan belajar quantum learning peneliti telah melakukan analisis kebutuhan dengan melakukan wawancara pada siswa dan guru pembimbing di SMA Negeri 3 Polewali. Didapatkan data kebutuhan siswa terkait dengan masalah belajar siswa. Adapun kebutuhankebutuhan yang terkait dengan masalah belajar siswa antara lain:

Penuturan siswa kelas X:

a. Apa Itu Kemandirian Belajar.

b. Apa Gunanya Belajar Bagiku

c. Bagaimana Penataan Lingkungan Belajar Yang Baik

d. Bagaimana Cara Menemukan Gaya Belajar Yang Menyenangkan !!!

e. Bagaimana Teknik Mencatat Tingkat Tinggi,

f. Bagaimana Teknik-Teknik Menulis Yang Cepat Dan Mudah !!!,

g. Bagaimana Menjadikan Membaca Sebagai Hobbi !!! 
h. Bagaimana Merayakan Keberhasilan Dalam Belajar.

i. Bagaimana Cara Memupuk Sikap Juara Dalam Belajar.

Setelah diketahui apa saja kebutuhan yang diperlukan oleh siswa terkait dengan perkembangan belajar siswa, kemudian disusun materi sesuai dengan kebutuhan-kebutuhan yang terkait dengan bimbingan belajar quantum learning. Rumusan materi disusun berdasarkan masalah belajar siswa, adapun materi-materi pada bimbingan belajar quantum learning di kembangkan dari kebutuhan-kebutuhan siswa adalah sebagai berikut: Apa Itu Kemandirian Belajar, Belajar Apa Gunanya Bagiku, Pentingnya Penataan Lingkungan Belajar, Memupuk Sikap Juara Dalam Belajar, Mari Menemukan Gaya Belajar Anda !!!, Mari Jadikan Membaca Sebagai Hobbi !!!, Teknik Mencatat Tingkat Tinggi, Temukan TeknikTeknik Menulis Yang Cepat Dan Mudah !!!, Mari Merayakan Keberhasilan Dalam Belajar. Model bimbingan belajar quantum learning yang digunakan dan di kembangkan dalam penelitian ini adalah milik Bobbi DePorter \& Mike Hernacki.

\section{Hasil Uji Validasi Ahli}

Berdasarkan hasil penilaian validasi uji ahli, untuk penilaian aspek isi panduan/model dan aspek kesesuaian dan kebermanfaatan model bimbingan belajar quantum learning untuk siswa, peneliti melibatkan empat ahli, ahli bimbingan dan konseling (Dosen BK UNM) yaitu Syahril Buchori, S.Pd., M.Pd dan Prof. Dr. H. Alimuddin Mahmud, M.Pd, dua ahli praktisi (Koordinator dan guru BK di SMA Negeri 3 Polewali) yaitu Abdullatif Ali, S.Ag., M.Si dan Syahriani, S.Pd, M.Pd. di simpulkan bahwa model bimbingan belajar quantum learning untuk siswa dalam peningkatan kemandirian belajar telah layak di berlakukan.

\section{Revisi I}

Revisi model awal ini dilakukan berdasarkan data hasil uji ahli. Beradasarkan data yang masuk dari para ahli dan dianalisis dan hasil analisisnya, pada dasarnya keempat ahli mengatakan bahwa model bimbingan belajar quantum learning untuk meningkatkan kemandirian belajar siswa yang telah ada sudah baik untuk digunakan dan diberikan kepada siswa. Meskipun demikian ada beberapa saran yang diberikan oleh para ahli. Adapun revisi yang dilakukan adalah revisi terhadap model bimbingan belajar quantum learning dalam meningkatkan kemandirian belajar siswa yang sedang dikembangkan

\section{Revisi II}

Revisi kedua dilakukan berdasarkan data hasil uji kelompok kecil yang dilakukan sebanyak sembilan tahap kegiatan pelaksanaan model bimbingan belajar quantum learning. Kesembilan tahap kegiatan model bimbingan belajar quantum learning yang di lakukan oleh peneliti, adapun proses pelaksanaan kegiatan secara umum yang dilakukan meliputi persiapan, penyampaian, pelatihan dan penilaian atau evaluasi. Hasil data yang masuk dijadikan sebagai bahan analisa dalam melakukan revisi kedua model bimbingan belajar quantum learning, dan merupakan acuan untuk menghasilkan produk akhir. Berdasarkan data yang diperoleh menunjukkan bahwa model bimbingan belajar quantum learning untuk meningkatkan kemandirian belajar siswa tidak perlu direvisi. Adapun revisi tahap dua lebih didasarkan pada data kualitatif, berupa saran dan komentar dari siswa.

5. Model Akhir Bimbingan Belajar Quantum Learning

Pada tahap ini, panduan model bimbingan belajar quantum learning telah mencapai tahap akhir dimana model bimbingan quantum learning sudah mampu digunakan sebagai panduan bagi guru pembimbing di sekolah. Setelah melaksanakan tahapan-tahapan penelitian di atas, maka lahirlah model pembelajaran quantum learning yang telah di uji oleh ahli, baik melalui uji validasi ahli maupun uji kelompok kecil yang dapat meningkatkan kemandirian belajar siswa di SMA Negeri 3 Polewali.

\section{SIMPULAN DAN SARAN}

Berdasarkan analisa data dan
pembahasan hasil penelitian, maka dapat
disimpulkan bahwa: (1) Pengembangan model
bimbingan belajar quantum learning untuk
meningkatkan kemandirian belajar siswa sangat
dibutuhkan di SMA Negeri 3 Polewali. (2)
Pengembangan model bimbingan belajar
quantum learning untuk meningkatkan
kemandirian belajar siswa melalui uji
keterpakaian (akseptabilitas) mendapat penilaian
baik dan uji keberterimaan mendapat penilian
cukup baik, yaitu dapat diterima dan digunakan
di SMA Negeri 3 Polewali. (3) Pengembangan
model bimbingan belajar quantum learning


untuk meningkatkan kemandirian belajar siswa yang dikembangkan berupa buku panduan yang terdiri aspek tujuan, sasaran, sarana pendukung, peran konselor, prosedur pelaksanaan dan evaluasi kegiatan.

Sehubungan kesimpulan penelitian di atas, maka diajukan saran-saran sebagai berikut: (1) Bagi Dinas Pendidikan dan Kebudayaan Kabupaten Polewali, agar dapat merekomendasikan kepada guru BK untuk menggunakan model bimbingan belajar quantum learning untuk meningkatkan kemandirian belajar siswa. Adanya model bimbingan belajar quantum learning, diharapkan dapat menjadi pedoman guru BK dalam menyusun dan melaksanakan program bimbingan belajar. (2) Adanya model bimbingan belajar quantum learning ini, diharapkan dapat memacu guru BK dalam menghasilkan program bimbingan lain seperti karir, sosial, dan pribadi yang secara khusus benar-benar diperuntukan sesuai kebutuhan siswa di sekolah. (3) Bagi peneliti dan mahasiswa program studi bimbingan dan konseling, hasil penelitian pengembangan ini dapat dijadikan salah satu contoh dalam penyusunan pengembangan program bimbingan dan konseling yaitu program bimbingan sosial, karir dan pribadi serta dapat mengembangkan model bimbingan belajar quantum learning ini lebih lanjut.

\section{DAFTAR RUJUKAN}

Ahman. (1990). Konstribusi Tingkat Penerapan Prinsip Bimbingan Dalam Proses Bimbingan Akademik Terhadap Kemandirian Belajar Mahasiswa. Tesis. FPS.IKIP Bandung: Tidak Diterbitkan.

Arikunto, S. 2002. Metode Penelitian Suatu Pendekatan Praktek. Jakarta: PT. Rineka Cipta.

Asim. 2001. Penulisan Laporan Penelitian Pengembangan. Malang: Universitas Negeri Malang.

Basri, M. 2005. Performance Appraisal: Sistem Yang Tepat Untuk Menilai Kinerja Karyawan Dan Meningkatkan Daya
Saing Perusahaan. Rajagrafindo Persada. Jakarta.

Basrowi \& Suwandi. 2008. Memahami Penelitian Kualitatif. Jakarta: Rineka Cipta.

Baumgartner, L. M. (2003). Self-directed learning: A goal, process, and personal attribute. In L. Baumgartner (Ed.), Adult learning theory: A primer, (pp. 23-28). Columbus, $\mathrm{OH}$ : Center on Education and Training for Employment. http://cete.org/acve/ majorpubs.asp

Borg, W \& Gall, M 1983. Education Research and Introduction. Fourth Edition. New York: Longman Inc.

Burtiham. (1999). Program bimbingan dalam membantu tugas perkembangan kemandirian belajar siswa tuna netra dirtingkat dasar SLBN A.Tesis BP SPS IKIP Bandung: Tidak Diterbitkan.

Cullough, Mc. 2014. Accelerated Learning Techniques For Student: Learn More In Less Time. New York: Amason.

DePoter, B \& Hernacki, M. 2000. Quantum Learning: Membiasakan Belajar Nyaman dan Menyenangkan, Ahli Bahasa:Alwiyah Adbulrahman, Bandung: Kaifa.

Gibbons, M. (2002). The Self-Directed Learning Handbook: Challenging Adolescent Students to Excel. San Fransisco, CA: Jossey-Bass.

Grieve M, 2003. A. Modern Herbal Patchoulli. www.Botanical.com.

Hadi, S. 2001. Statistik, Jilid 1. Yokyakarta: Andi Offset.

Hiemstra, R. (1991). Self-Direction In Learning: Prespectives. On Theory, Research, And Practice. New York

Johnson,E.B .(2002). Contextual Teaching And Learning. What It Is And Why It Here To Stay. California: Corwin Press,inc. 
Kartadinata, S. 1998. Landasan-Landasan Sekolah Dasar. Jakarta: Depdikbud.

Kesten, C. (1991) Understanding the Common Essentials Learning: Saskatchewan Education.

Maher, A \& Zins, E. 2006. Kemandirian Peserta Didik Dalam Belajar. Ahli Bahasa: Nuranisah. Jakarta. PT Asdi Mahasatya.

Marjohan. 2007. Kemandirian dalam Belajar Perlu Ditingkatkan. (online). Tersedia:http//penulisbatusangkar.bl ogspot.com (diakses tanggal 29 januari 2015).

Marsudi, S. 2003. Layanan Bimbingan dan Konseling di Sekolah. Surakarta: Muhammadiyah University Press.

Mashuri, M. 2007. Perencanaan dan Pelaksanaan Pembelajaran. Semarang: Karya Mandiri.

Merriam, S., \& Caffarella, R.S. (1999). Learning in Adulthood. San Fransisco : Jossey Bass.
Mulyasa, E. 2002. Manajemen Berbasis Sekolah konsep, strategi, dan implementasi. Bandung: PT Remaja Rosda Karya.

Nasution, M. 2000. Metode Research (Penelitian Ilmiah). Jakarta: PT. Bumi Aksara.

Prayitno \& Amti, E. 2004. Dasar-dasar Bimbingan dan Konseling. Jakarta: Rineka Cipta.

Prayitno. 2004. Pelayanan Bimbingan dan Konseling. Jakarta: DIKTI. 